\title{
Omnipresent Social Media: Is Travelling Imaginable without Smart Devices?
}

\author{
Zsuzsanna Marton \\ University of Pannonia, Hungary \\ marton.zsuzsanna@uni-pen.hu \\ Ildikó Ernszt \\ University of Pannonia, Hungary \\ ernszt.ildiko@uni-pen.hu
}

As earlier people went on holidays for the relaxation and the feeling of escape from the ordinary weekdays, nowadays most of them cannot imagine to spend a few days without internet connection or their smartphones during travels. The benefits of using smart phones and social media cannot be questioned, however, the drawbacks have to be also considered. To reveal the cons and pros of the phenomenon, first a brief theoretical overview of the topic is introduced, and then the analysis of the results of the empirical research involving 386 people in Hungary are put into the focus of this paper. The online survey conducted in Autumn 2019 gave the opportunity to study the mobile phone and social media usage habits of the Hungarians during their holidays. Simple descriptive statistics and the method of multidimensional scaling (MDS) with ALSCAL procedure were applied to illustrate the perceptions and attitudes of the respondents, and to interpret the hidden relationships among the variables. The results show that the smart tools and social media are organic parts of the holidays: $90 \%$ of the respondents use social media platform like Facebook daily, and $48 \%$ said that they use their mobile phones less during holidays compared to the everyday. However, only $13.5 \%$ of them would be willing to mitigate the usage of smart devices totally, while in case of social media usage this proportion is higher, $37.9 \%$.

Key Words: tourism, smart tools, social media, consumer behaviour, digital detox

JEL Classification: Z33

https://doi.org/10.26493/1854-6935.18.301-321

\section{Introduction}

Digital transformation is not optional anymore; all sectors are highly exposed to it, which brought considerable changes in consumer behaviour and in the whole environment of the insdustries (Tomičić Fur- 
jan, Tomičić-Pupek, and Pihir 2020; Marušić et al. 2019; Bach et al. 2019; Gössling 2021). The importance of using modern technology, social media in tourism sector is recognised by most service providers (Paliokas et al. 2020). However, there are still some cultural institutions in the world, which are reluctant to use digital solutions which could make them to be more visible (Akca 2020).

In the digital era, the info-communication and technological (hereinafter ICT) innovations have also significantly changed the consumer behaviour of tourists. The opportunities provided by the smart tools, the applications and the different online platforms make the travel decisionmaking process easier, faster and more transparent. The tools are colorful: travel recommender systems, even data mining applications were developed (Renjit, Sreekumar, and Jathavedan 2020; Bach et al. 2019). People often choose their next destinations based on others' reviews, photos or suggestions, book their flights and the accommodations on their mobiles, and share their real-life holiday experiences via smart tools. A research made in Malaysia revealed, that the social media is the strongest influencing factor for millennials when making domestic travel decisions (Moorthy et al. 2020).

Social media had an important role even in case of group travels, since in certain situations it is vital in replanning the on-site activities, getting information about local news and connecting to travel mates and family at home (Fardous, Du, and Hansen 2020). Furthermore, social media can also contribute to getting knowledge about the destination, and to sociological adaptation ( $\mathrm{Li}$ et al. 2020).

Thanks to the Internet and social media, more and more destinations can open their gates for potential travellers. Travellers may reach destinations, they have never heard about before, and make them known for others by sharing their experiences immediately on site, which facilitates the phenomenon of overtourism. Therefore, it is important to make decisions consciously and think over their long-term effects in the sake for sustainable development and responsible behaviour (Moric 2013).

The tourists' behaviour and their needs have gone through a considerable change that also have made a shift in the supply side of the destinations. In the mid of the 2oth century, when mass tourism started to flourish, people wished to travel to destinations providing the combination of 'sun, sea and sand' (Aguiló, Alegre, and Sard 2005). The destinations and service providers struggled to build their activities on this combination that strongly depended on seasonality and the tourism infrastruc- 
ture. Therefore, many destinations left out of tourism due to the lack of 'basic' elements of the touristic operations. More and more destinations recognized the potential in tourism and started to consciously build out the basic and touristic infrastructure. Not only the 'sun and sand' destinations benefited from tourism, but also the destinations with natural or cultural attractions can enter the tourism market. Destination marketing organizations, national tourism organizations also use social media as a marketing tool, meanwhile it could also be utilized as a customer service tool (Usakli 2017; Curlin, Pejić Bach, and Miloloža 2019; Molina et al. 2020).

Social networks can also help in the branding of different destinations or service providers (Blace, Coric, and Juric 2015; Huerta-Alvarez, Cambra-Fierro, and Fuentes-Blasco 2020; Peco-Torres, Polo-Pena, and Frias-Jamilena 2020; Barreda et al. 2020; Moro and Rita 2018; Yu, Xie, and Wen 2020). Seo, Park, and Choi (2020) conducted a research among airline social media users about 'the effect of social media usage characteristics on electronic word-of-mouth (e-woM), trust, and brand equity'. It turned out, that the e-wом had determining impact on trust, brand awareness and brand image (Seo, Park, and Choi 2020).

However, the attractions themselves are not satisfying for the tourists anymore. They want experiences that they can share offline (with their travel companions) and online (with their fellows on social media (Falk and Hagstein 2020). Behind the travel motivation, there is often a push from friends on social media, who post their travel experiences on photos or videos (Aggarval and Gour 2020; Latif et al. 2020). Mainly the younger generations do not want to lag, and target the next tourist destinations under this pressure. Being continuously online and using our smart tools without stop pervade our holidays, as well. Using the navigation, searching for good-rated restaurants, reading QR codes for getting information on site are all the parts of holidays for better tourist experiences and satisfactions. Moreover, these experiences have to be or must be shared on social media that also needs the inevitable use of smart tools. Social media has become a fundamental attribute of holidays, which creates an interactive platform for communication being beneficial to all parties ( $\mathrm{Ai}, \mathrm{Lv}$, and Gursoy 2020). Reviews, feedback written by the users are not only useful for other tourists, but also the service providers can benefit from them (Leung et al. 2013). Social media can support the increase in effectiveness of knowledge management and business operations of the companies, services providers (Kašćelan et al. 2020). To be able to maintain 
the competitiveness and increase the market share on the market, service providers have to keep up with the latest social media trends and to identify the opportunities and react in time (Mabić, Gašpar, and Lucović 2017).

The advantages of the Internet and social media are undoubted, however, the focus has started to divert from the original purpose of holidays just, for example, stepping out from the weekdays, relaxing or discovering. This paper aims to study the role of social media and mobile use in tourism based on a literature overview, and to reveal the tourists' habits of use of smart tools, as well as social media on holidays. 386 Hungarian people were involved in the empirical research.

\section{Literature Review}

THE IMPACT OF MOBILE USAGE ON TOURISTS'BEHAVIOUR

By the spread of smart phones and tools, calling and texting have become secondary functions, and the opportunities provided by these smart tools (e.g. social networking, information search, weather forecast) got into focus (Yang 2013; Tan et al. 2017). By using mobile devices during travel gives the opportunity the tourists to be more connected, confident, informed and safe (Wang, Xiang, and Fesenmaier 2016). However, there are several benefits of mobile usage, that can make our lives and holidays more convenient, the number of disadvantages is not negligible. According to Travelers Today (2019), people use mobile devices for navigation, translation, information search, booking, as well as to keep in touch with friends, to share on social media, either to download travel applications or use travel guides. Nevertheless, the (excessive) use of these tools can cause distraction, poor concentration on attractions, the lack of experience, and less mindfulness.

Travel experts, portals predict that the importance of modern technology will even increase in the post-covid world. It will be essential for travellers to get the latest travel information (Tourwriter 2020). A survey carried out by Censuswide revealed, that the trust of more than $80 \%$ of travellers would be heightened because of modern technology in the next year. Regarding this trust, most of them $(42 \%)$ have referred to a special mobile application giving them alerts, notifications during their trip about possible safety and security threats. Contactless payments and mobile boarding would also be suitable to increase their confidence to travel' Amadeus 2020). The role and the significance of mobile use are de- 
cisive only during travel, but it has an impact on the whole travel decisionmaking process, too.

Making travel decision can be regarded as a quite complicated process that requires various information sources in different phases. The information search process is very crucial from the destination choice's point of view (Bieger and Laesser 2004; Jacobsen and Munar 2012). The Internet and IC T tools have brought a fundamental shift in consumer behaviour of tourists already from the first step of the decision-making process. The smartphones in people's pockets have become a perfect travel companion throughout the whole journey (Thinkwithgoogle 2016).

Mobile devices are important tools of getting tourism information (Lin, Juan, and Lin 2020). According to the findings of 'think with Google' research among us people, the $60 \%$ of destination information searches were carried out by mobile devices, while the $31 \%$ of the leisure travellers and more than half of the business travellers booked on smartphones. Regarding the top travel activities, $44 \%$ of the respondents searched for discounted offers, 35 and $32 \%$ looked for destination-related information before visiting the destination and during their staying. The key findings of this research show that people desire simplicity and convenience while they use their smartphones in connection to travel.

While Thinkwithgoogle (2016) analysed usage habits from a practical perspective, Pavelka (2016) studied smartphone use during travel from the psychological side, as well. The feeling by using smartphones during travel was in the focus of the research. Based on the results of the survey conducted in the UK, $98 \%$ of the UK respondents, the travel is more comfortable by using smartphones; $78 \%$ of them feel safer with using a smartphone.

Other research in the UK (Dickinson et al. 2014) analysed the importance of mobile applications during travel that has to be more personalized, and have to keep up with the latest consumer trends and needs. Mobile apps with numerous functions drive tourists to download them since with their usage the trip can be easier. Even though these applications are getting more popular, $82 \%$ of us people have never paid for downloading apps, rather use free options (Thinkwithgoogle 2016). According to this $\mathrm{UK}$ research, the top motivating factor for downloading travel apps is to make a specific activity or task easier (36\%). $32 \%$ of the respondents was motivated to download by other recommendations and to access discount and offers during travel. Using mobile applications undoubtedly make the trip easier, and might make it more meaningful and 
informative, however, the questions arise, how tourists can live the experiences while they are stuck to the screen.

SOCIAL MEDIA AND TRAVEL DECISION-MAKING

Millions of people use social media sites daily, which became the primary communication platforms among the most of age groups (Balan and Rege 2017). Social media has affected consumers' lives in many ways: how they perceive the world and their surrounding environments, how they see others, how they manage the daily tasks, just as purchase processes (Månsson 2011). The research of Yang and Wong (2020) revealed a special aspect of social media during the covid pandemic: the social media presence and activity functions as a means of distraction the negative stress regarding COVID-19 quarantine.

The role and the impact of social media in tourism is unquestionable. On the one hand, it influences tourists' behaviour and business performance, on the other hand, it has an effect on the way how the tourists perceive the experiences, what posts they do, what content they share (Law, Buhalis, and Cobanoglu 2014). Businesses, service providers already recognized that how they can influence their customers and how they engage them to choose their services (Nayak, Nayak, and Jena 2020).

Deciding on the potential target destination is never easy since it is based on a multistep model influenced by many factors (Woodside and Lysonski 1989). Technological innovations (e.g. the evolution of Web 1.0 to two-way communication sites (Web 2.0 and 3.0) brought new concepts on the tourism market as well. Under the concept of Travel 2.0 consumers are empowered by information, they can easily have access to everything (e.g. experiences, services, and everybody (other travellers and non-travellers) (Miguéns, Baggio, and Costa 2008; Roblek et al. 2013). Creating, consuming and diffusing travel information through the Internet in the frame of consumer generated content (CGM) all contribute to a new approach to the travel decision-making (Al-Tit, Omri, and Hadj 2020). The feedback given by the tourists on social media can boost the service quality in the future, which increases revisit intension, as well (Markus et al. 2019).

More researches were conducted about the topic, in which travel phases tourists use social media most (Balouchi and Khanmohammadi 2015; Hussain, Li, and Wang 2018). The decision-making process can be divided into three main phases (before, during and after) in which social media has certain roles according to Dwityas and Briandana (2017). 
In the pre-trip phase, collaboration and interaction are mostly determining. The first trait of social media in this process can be traced back to the birth of motivation. In many cases, people are motivated by a photo uploaded on Facebook or Instagram, and then start to gather specific information about the destination itself, and make the final choice. Travel communities, blogs, booking or comparative websites all can help the decision-making. In this phase, the trust is social media is very important, because the reliability and the relevancy of information are questionable (Tang and Liu 2015). Consumers interact with each other, share their past experiences, make ratings.

In the 'during trip' phase, content sharing gets more importance. Li's academic studies have focused on the analysis of the motivations lagging photo-taking and sharing behaviours during travel (Munar and Jacobsen 2014; Li 2020; Sotiriadis 2017; Pan, Lee, and Tsai 2014). Based on their findings, the recognition and status, the enjoyment, the disclosure and the information-giving, external expectations drive people to post and share photos and videos about their trips.

Furthermore, another study pointed out the significance of sharing and posting in the post-trip evaluation. According to Kim and Fesenmaier (2017), those travellers who share their experiences on social media give more positive post-trip evaluations than who do not share. Taylor investigated the effects of certain psychological features of travellers regarding sharing photographs in social media. The research strengthened, that narcissism, envy contribute to the sharing travel photos in social media as a tool for self-promotion (Taylor 2020).

Tourism experience, which is regarded as a multi-phased, activitybased process and phenomenon (Wang, Park, and Fesenmaier 2012; Gretzel, Fesenmaiers, and O'Leary 2016), does exist in all stages of trip (pre, during and post). It is highly affected by social media through the stages that evokes emotions and physiological processes (Holbrook and Hirschman 1981; Kim and Fesenmaier 2017).

\section{DIGITAL DETOX IS THE NEW TREND}

As it was mentioned, digital tools are organic parts of our lives that eventually force us to be continuously online and available for everyone in every minute. The use of modern tools is both a blessing and a curse in our lives, because on the one hand, they help to make our daily lives easier, on the other hand, they have taken control of us, they demand participation in almost every moment of our lives. 
Involving in the digital world starts at a younger age: research conducted by Huawei Technologies Hungary among Generation Y parents shows that about $90 \%$ of preschoolers between the ages of 4-6 use smart devices. In spite of this fact, the parents themselves believe that these kinds of smart tools should be put in the hands of children much later (Világgazdaság 2020).

Continuous digital existence, digital 'readiness' is also typical during travel. In addition, many find it difficult to bear the 'continuous' presence of modern technology, the never-ending 'online' state, which is quite exhausting, as in many cases it is already at the expense of rest and complete relaxation.

However, the continuous 'readiness' has been a trend, there was an urgent need to compensate its adverse effects, so a new trend against it appeared, which is called as digital detox (Pawlowska-Legwand and Matoga 2020; Egger, Lei, and Wassler 2020; Fan, Buhalis, and Lin 2019).

More and more people have recognized the need for giving up to be online and to escape from the digital world for a while. Even if we do not eliminate the usage of smart tools and social media platforms from our weekdays, the holiday is an excellent time to start excluding. Wilcockson, Osborne, and Ellis (2019) studied the so-called heavy mobile-users in laboratory after 24 hours from the smart tool withdrawal. After the withdrawal, the feelings and the general mood of the participants immediately decreased, however, by the end of the day, they started to be more relaxed and less stressful. Another research (Cai, McKenna, and Waizenegger 2019) examined the emotional states of the survey participants in three phases during their travel after the withdrawal of digital tools and social media platforms. The research brought similar results, the participants became more relaxed as the time went by, they enjoyed the holidays, and spent more meaningful time with their travel companions.

\section{Methodology}

In this chapter, the focus is on the introduction to the research instruments, the data and the sample characteristics, the applied statistical methods, as well as the validity of the research.

\section{RESEARCH INSTRUMENTS}

Our research aimed to reveal and analyse the smart device usage habits of people during their travel. A quantitate research was conducted in 2019 
TABLE 1 Structure of the Online Questionnaire

\begin{tabular}{ll}
\hline Question block & Description \\
\hline 1 General travel habits & $\begin{array}{l}\text { Frequency of travel } \\
\text { Motivation }\end{array}$ \\
\hline 2 Mobile phone usage habits during travel & Used smart devices \\
& Used smart phone functions \\
& Willingness to mitigation of smart phone \\
\hline 3 Social media usage habits during travel & Used social media platforms \\
& Frequency of posts \\
& Willingness to mitigation of smart phone \\
\hline 4 Socio-demographic data collections & Age, gender, education, occupation \\
\hline
\end{tabular}

Autumn in the frame of an online survey involving 386 respondents in Hungary. Based on the theoretical overview, question blocks with specific items were defined for compiling the questionnaire (table 1). The following research questions were drafted:

RQ1 How much does smartphone pervade the holidays of the respondents and which functions are determining concerning the usage?

RQ2 How much do social media and mobile usage affect the holidays? In what degree are the tourist able to mitigate their usage? How does age affect it?

\section{DATA}

Regarding the demographics (table 2) of the survey sample as shown in table $1,71.2 \%$ of the respondents were female, $28.8 \%$ was male. Most of them (69.9\%) belong to the youngest age group (18-25), 8.3\% represents the age group between $26-35$ years. The respondents aged between $36-$ 45 years are up to $8.3 \%$ in the sample, people above 45 represent ca. $10 \%$. Based on the highest education level of the respondents, those who have secondary school education showed the highest proportion, which is resulted in the large proportion of the youngest in the sample. Concerning the travel habits, the $61.7 \%$ of the respondents travel once or two times a year, $22.5 \%$ travel three or four times.

\section{STATISTICAL METHODS}

To get a reply to the research questions above and to reveal the attitudes and perceptions of the respondents, descriptive statistical analyses (e.g. frequencies, crosstabs - Chi-square test) and the method of multidimensional scaling (MDS) with ALSCAL procedure were applied. The MDS 
TABLE 2 Sample Profile

\begin{tabular}{|c|c|c|c|}
\hline Category & Item & $n$ & $\%$ \\
\hline \multirow[t]{6}{*}{ Age group } & $18-25$ years & 270 & 69.9 \\
\hline & $26-35$ years & 32 & 8.3 \\
\hline & $36-45$ years & 45 & 11.7 \\
\hline & $46-55$ years & 21 & 5.4 \\
\hline & $55-65$ years & 13 & $3 \cdot 4$ \\
\hline & $>65$ years & 5 & 1.3 \\
\hline \multirow[t]{2}{*}{ Gender } & Female & 275 & 71.2 \\
\hline & Male & 111 & 28.8 \\
\hline \multirow[t]{4}{*}{ Education } & Primary school & 11 & 2.8 \\
\hline & Secondary school & 302 & 78.2 \\
\hline & College/university & 70 & 18.1 \\
\hline & Postgraduate/PhD & 3 & 0.8 \\
\hline \multirow[t]{6}{*}{ Occupation } & Student & 240 & 62.2 \\
\hline & Entrepreneur & 9 & 2.3 \\
\hline & Public sector employee & 42 & 10.9 \\
\hline & Private sector employee & 88 & 22.8 \\
\hline & Retired & 1 & 0.3 \\
\hline & Other & 5 & 1.3 \\
\hline \multirow[t]{4}{*}{ Frequency of travel } & Not every year & 8 & 2.1 \\
\hline & 1-2 times a year & 238 & 61.7 \\
\hline & $3-4$ times a year & 87 & 22.5 \\
\hline & $>4$ times a year & 53 & 13.7 \\
\hline
\end{tabular}

model by creating a perception map illustrates the perceptions and preferences of the respondents in two-dimensional space (Malhotra 2002). Stress-value is the goodness-of-fit statistic that MDs tries to minimize; its value varies between 0 and 0.2 . The less the value of stress is, the better the fit is (Wilkinson 2013, 188). The statements in the questionnaire had to be evaluated by the respondents on 5-point Likert scales. For the analysis of relationships one-way ANOvA is used on 5\% significant level.

\section{VALIDIT Y}

The research questionnaire was compiled based on the relevant literature and earlier market researches introduced in the previous chapters, fur- 
TA B LE 3 The Popularity of Daily Usage of Different Smart Tools among the Respondents

\begin{tabular}{lrr}
\hline Item & No & Yes \\
\hline Smart phone & 2.1 & 97.9 \\
Tablet & 84.2 & 15.8 \\
Smart watch & 92.0 & 8.0 \\
Activity tracker & 94.3 & 5.7 \\
Other & 97.9 & 2.1 \\
None & 98.7 & 1.3 \\
\hline
\end{tabular}

NOTES In percent.

thermore, the applied methods followed them by using 5-point Likertscale, which is generally accepted and validated measurement scale.

\section{Results}

ANALYSIS OF TOURISTS' HABITS BASED ON SMART DEVICES'

USAGE: THE ROLE OF SMART FUNCTIONS

Regarding the usage of smart devices, smartphone usage is the most determining, $98 \%$ of the respondents use it daily. Using other smart tools like tablet or activity tracker is not so popular, only $5-15 \%$ of them use these tools daily (table 3).

Smart devices provide several opportunities that make holidays more comfortable and easier for tourists (table 4). $82.64 \%$ of the Hungarian respondents uses smart devices for contacting others. Navigation function can be regarded as important as chatting, since approximately $79 \%$ takes advantage of it. The results show that having smartphones or other smart tools makes people more confident, even though they do not bring it in parallel to the sense of safety and security. Surprisingly, the majority of the respondents $(75 \%)$ do not use smart devices for gathering information during travel.

As the result of the MDS configuration (figure 1), we can see that the respondents link certain items together in their perception. The stressvalue is 0.01220 meaning that the map is more than suitable for reliable interpretation, the results are significant.

According to the perceptions (distances between the points along the coordinate axis) survey participants differentiate four areas regarding the smart phone functions in two dimensions. Dimension 1 can be interpreted as the degree of importance of the smart phone functions. To 
TABLE 4 Smart Device Functions Used during Travel

\begin{tabular}{lrrrrrr}
\hline Function & 1 & 2 & 3 & 4 & 5 & Mean \\
\hline Information & 3.9 & 0.5 & 13.0 & 35.8 & 46.9 & 4.2 \\
Photos. videos & 3.1 & 4.1 & 13.5 & 26.9 & 52.3 & 4.2 \\
Navigation & 3.9 & 3.9 & 14.2 & 30.1 & 47.9 & 4.1 \\
Sense of security & 6.0 & 5.7 & 5.7 & 5.7 & 5.7 & 3.9 \\
Chat & 10.1 & 15.5 & 23.6 & 24.6 & 26.2 & 3.4 \\
Confidence & 15.8 & 18.4 & 27.5 & 23.1 & 15.3 & 3.0 \\
Post & 35.0 & 28.8 & 21.5 & 9.6 & 5.2 & 2.2 \\
Play & 55.4 & 20.2 & 13.5 & 5.7 & 5.2 & 1.9 \\
Payment & 57.8 & 17.6 & 11.1 & 9.1 & 4.4 & 1.8 \\
\hline
\end{tabular}

NOTES 1 - not at all agree, 5 - totally agree.

FIGURE 1

Perceptual Map of Smart Device Functions

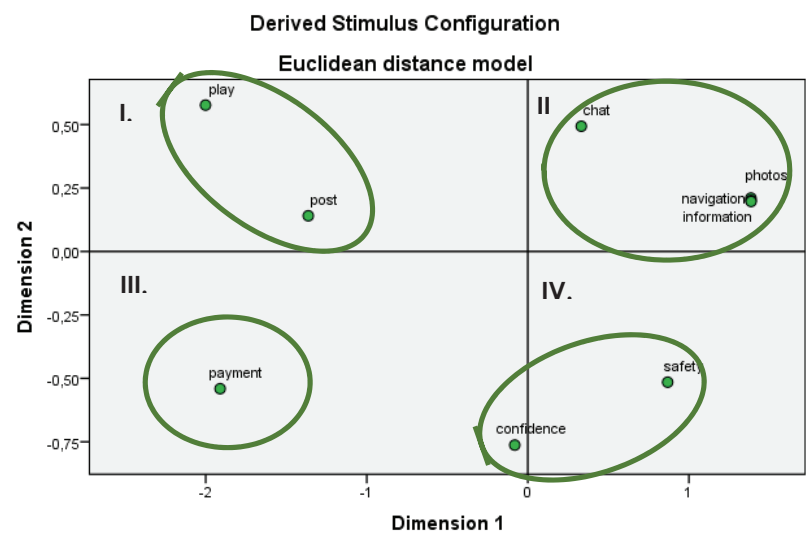

the right of the origo, those functions are located which are more important for the participant, at the opposite side of the dimension, the less preferred items can be found. The interpretation of Dimension 2 is more theoretical. The two opposite end-points of the axis can regarded as 'safety' (below) and 'pastime or entertainment' (above). We can see that the Hungarians perceive photo-taking, information-getting and navigation exactly in the same way. Not only they are just as important for the tourists, but also the respondents associate them with very similar content and needs. Eventually, these three functions (information, navigation and photo/video-taking) are the core and essential activities during travel. However, the chat function is located in this quarter of the coordinate system (perceptual map), it is further from the previous three functions. 
TABLE 5 Cluster-Based Approach of Functions Based on MSD Results

\begin{tabular}{lll}
\hline Main cluster & Sub-cluster & Items \\
\hline 1 Fully emotional & Entertainment & $\begin{array}{l}\text { Playing } \\
\text { Posting }\end{array}$ \\
\hline 2 Emotional \& functional & Communication & Chat \\
& \& information & $\begin{array}{l}\text { Photo-taking } \\
\text { Navigation }\end{array}$ \\
& & Information-search \\
\hline 3 Fully functional & Payment & Payment \\
\hline 4 Emotional \& functional & Safety & Feel of safety \\
& & Feel of confidence \\
\hline
\end{tabular}

According to the interpretation of the dimensions, chat has more entertainment function. Playing on smartphones and posting on social media are perceived not only less important, but also playing is particularly for entertainment. In the below quarters, the safety element of the functions is dominant. Using smart phones provides safety and makes people more confident, just as the payment function of them does. Nevertheless, the last one is less important for the survey participants. According to the results of the perceptual map, functions can be categorized based on the degree of emotional benefit (table 5).

\section{SOCIAL MEDIA AND SMART PHONE USAGE HABITS DURING HOLIDAY - THE DEGREE OF WILLINGNESS OF USAGE MITIGATION}

As it was described in the literature overview, social media is the organic part of our lives. The survey results also underpin this statement, hence almost $90 \%$ of the respondents use Facebook daily, $64 \%$ of them use Instagram. Concerning the social media presence during the holiday, $48 \%$ of the Hungarians never post from holidays, $19 \%$ does every day. The perceptual map also illustrated, that posting on social media is not really important $(m=2.2)$.

According to the replies, the Hungarians try to mitigate the usage of smart tools during the holiday, since $78 \%$ said that they used less them compared to everyday habits. The analysed age groups did not show any significant differences based on one-way ANOVA analysis $(p=0.054)$ on 5 percent significance level, each group struggles to use less. Even the elders (aged above 65) represent the highest mean value $(m=2.50)$ (table 6).

However, only half of the respondents $(50.8 \%)$ would be willing to 
table 6 anova Table for the Mitigation of Social Media and Mobile Usage by Age Groups

\begin{tabular}{llrrrrr}
\hline Category & & $(1)$ & $(2)$ & $(3)$ & $(4)$ & $(5)$ \\
\hline Mitigation of smart devices & Between Groups & 14.805 & 5 & 2.961 & 2.195 & 0.054 \\
& Within Groups & 512.534 & 380 & 1.349 & & \\
& Total & 527.339 & 385 & & & \\
\hline Mitigation of social media & Between Groups & 26.959 & 5 & 5.392 & 4.090 & 0.001 \\
& Within Groups & 499.602 & 379 & 1.318 & & \\
& Total & 526.561 & 384 & & & \\
\hline
\end{tabular}

Notes Column headings are as follows: (1) sum of squares, (2) degrees of freedom, (3) mean square, (4) $F$, (5) significance.

TABLE 7 The Willingness to Mitigate Smart Devices and Social Media Use During Travel

\begin{tabular}{lrrrrrr}
\hline Item & 1 & 2 & 3 & 4 & 5 \\
\hline Smart Devices & 8.3 & 19.9 & 21.0 & 37.3 & 13.5 \\
Social Media & 3.9 & 12.5 & 16.1 & 29.6 & 37.9 \\
\hline
\end{tabular}

NOTES 1 - not at all, 5 - totally. In percent.

eliminate its mobile usage during holidays. This proportion is higher $(67.5 \%)$ in case of the mitigation of usage of social media platforms (table 7).

The younger people testify more active social media presence than the older respondents. The respondents aged 18-25 post more frequently, hence sharing experiences more times a day characterizes them mostly. Respondents above 55 years do not post at all during their holiday.

In case of social media mitigation, the ANOva analysis showed significance difference between age groups $(p=0.001<0.05)$ (table 6). The biggest gap based on the means plot analysis, there is between the respondents aged $18-15$ and people above 65 years. Besides, the age group between 46-55 also stands out in the sample, after the youngest people, they are those who are willing to mitigate the least the social media usage during their trip.

\section{Discussion, Implication and Conclusion}

Technological innovations, the appearance of smart devices fundamentally changed the tourism industry, including the consumer behaviour of tourists. In our accelerated world, potential tourists are empowered 
by more information than ever, they can reach any destinations they want, and they can do all this via a smartphone or a smartwatch. They go nowhere without their smart 'buddies,' not even on holiday. Unfortunately, the holiday seems to lose its traditional value meaning relaxing or discovering with friends or families, instead, people travel to a destination just to show an image on social media, and keep up with others.

The present study confirms the current trend and the literature review, earlier market researches that smart devices undoubtedly became the organic parts of our lives. The survey results also justify the fact that people's holiday and related habits have considerably changed due to technological innovations and devices. During the holiday, smart devices can provide many advantages that make the holiday more comfortable. Navigation and chat functions are the most popular among the respondents, but they also prefer to take photos or play with smart devices.

Some forms of social media platforms are known by all respondents, but Facebook is the most beloved among them. Posting and sharing experiences on social media are rather preferred by the youngest tourists (18-25 years), the quarter of them post from holiday daily.

The results suggest that people want to get rid of using smartphones/ devices so much during holiday, however, only a minority of them would be willing to eliminate its usage during travel.

Not only researches confirmed that the consumer behaviour of the people changed due to the digitalization, but also consumers often admit that the disadvantaged and the excessive use of smart devices, especially during the holiday. The constant online mode can alter the quality of life and human relationships, too. In 2021 'working from anywhere in the world' has created the special notion of 'digital nomad visa, which creates the possibility of working from abroad for a longer period of time for remote workers' (Etias News n.d.).

In the tourism industry, the answer given to the above-mentioned trend is a new trend in the form of 'digital detox.' The service providers recognized that organizing a camp or tour focusing on digital detox could be a new market niche that should be more utilized in the future. As the survey results showed people involved in the survey also drew up the hidden need by saying that they try to mitigate the usage of smart devices and social media platforms.

However, the results gave a general overview of the current situation of the consumer behaviour related to smart tool and social media usage, and they are consistent with earlier study result, we have to mention the 
limitation of the research. The sample including 386 participants, but not representative for the Hungarian population (tourists). Furthermore, the survey questions focused only the 'during-trip' phase, while the before and after phases would be interesting from the perspective of social media usage.

Since the research was conducted in 2019 before the outbreak of CoviD-19, many changes might have occurred in tourists' behaviour. According to travel experts, portals, the importance of modern technology will even increase in the post-covid world further. The phased of decision-making process and the travels themselves have already been considerably affected by smart tools, however, its significance will be more dominant, and will become more inseparable part of our travels. Therefore, regarding future researches, there would be worth to analyse the impacts of COVID-19 on technological developments related to tourism industry and the attitude of the tourists towards them.

\section{Acknowledgments}

The preliminary version of the paper was presented at Entrenova 2020 Conference, Split, 10-12 September.

\section{References}

Aggarval, S., and A. Gour. 2020. 'Peeking Inside the Minds of Tourists Using a Novel Web Analytics Approach.' Journal of Hospitality and Tourism Management 45:580-91.

Ai, J., X. Lv, and D. Gursoy. 2020.'Impact of Social Media Posts on Travelers' Attitudes and Behaviors towards a Destination After a Natural Disaster: Moderating Role of the Source of the Post.' Journal of Sustainable Tourism. https://doi.org/10.1080/09669582.2020.1831002.

Akca, S. 2020. 'Museums in the Age of Technology and Information: Overview.' Turkish Librarianship 34 (2): 263-74.

Aguiló, E., J. Alegre, and M. Sard. 2005. 'The Persistence of the Sun and Sea Tourism Model.' Tourism Management 26 (2): 219-31.

Al-Tit, A. A., A. Omri, and T. B. Hadj. 2020. 'The Driving Factors of the Social Commerce Intention of Saudi Arabia’s Online Communities.' International Journal of Engineering Business Management 12:1-8.

Amadeus. 2020. 'Travel Trends in 2021 - Prepare for a Year of New Opportunities.' PhocusWire, 22 December. https://www.phocuswire.com/ Travel-trends-2021-year-of-changes.

Barreda, A. A., K. Nusair, Y. C. Wang, F. Okumus, and A. Bilgihan, A. 2020. 'The Impact of Social Media Activities on Brand Image and Emotional 
Attachment: A Case in the Travel Context.' Journal of Hospitality and Tourism Technology 11 (1): 109-35.

Bach, M. P., S. Seljan, B. Jaković, A. Buljan, and J. Zoroja. 2019. 'Hospital Websites: From the Information Repository to Interactive Channel.' Procedia Computer Science 164:64-71.

Balan, S., and J. Rege. 2017. 'Mining for Social Media: Usage Patterns of Small Businesses.' Business Systems Research: International Journal of the Society for Advancing Innovation and Research in Economy 8 (1): 43-50.

Balouchi, M., and E. Khanmohammadi. 2015. 'Using Logarithmic Fuzzy Preference Programming To Prioritization Social Media Utilization Based On Tourists' Perspective.' Foundations of Management 7 (1): 718.

Bieger, T., and C. Laesser. 2004. 'Information Sources for Travel Decisions.' Journal of Travel Research 42 (4): 357-71.

Blace, D., G. Coric, and B. Juric. 2015. 'Branding the City of Sibenik as a Sustainable Tourist Destination Using Social Networks.' Ekonomski vjesnik 28:9-124.

Cai, W., B. McKenna, and L. Waizenegger. 2019. 'Turning It Off: Emotions in Digital-Free Travel.' Journal of Travel Research 59 (5): 909-927.

Ćurlin, T., M. Pejić Bach, and I. Miloloža. 2019. 'Use of Twitter by National Tourism Organizations of European Countries.' Interdisciplinary Description of Complex Systems 17 (1B): 226-41.

Dickinson, J. E., K. Ghali, T. Cherrett, C. Speed, N. Davies, and S. Norgate. 2014. 'Tourism and the Smartphone App: Capabilities, Emerging Practice and Scope in the Travel Domain.' Current Issues in Tourism 17 (1): 84-101.

Dwityas, N. A., and R. Briandana. 2017. 'Social Media in Travel Decision Making Process.' International Journal of Humanities and Social Science 7 (7): 193-201.

Egger, I., S. I. Lei, and P. Wassler. 2020. 'Digital Free Tourism - An Exploratory Study of Tourist Motivations.' Tourism Management 79: 104098. https://doi.org/10.1016/j.tourman.2020.104098.

Etias News. N.d. 'Digital Nomad Visas in E U Countries' https://www .etiasvisa.com/etias-news/digital-nomad-visas-eu-countries.

Falk, M. T., and E. Hagstein. 2020. 'Visitor Flows to World Heritage Sites in the Era of Instagram.' Journal of Sustainable Tourism. https://doi.org/10 $.1080 / 09669582.2020 .1858305$.

Fan, D. X. F., Buhalis, D. and Lin, B. N. (2019). 'A Tourist Typology of Online and Face-to-Face Social Contact: Destination Immersion and Tourism Encapsulation/Decapsulation.' Annals of Tourism Research 78:102757. https://doi.org/10.1016/j.annals.2019.102757. 
Fardous, J., J. T. Du, and P. Hansen. 2020. 'Collaborative Information Seeking during Leisure Travelling: Triggers and Social Media Usage.' Information Research 24 (3): 830.

Gössling, S. 2021. 'Technology, IC T and Tourism: From Big Data to the big Picture.' Journal of Sustainable Tourism 29 (5): 733-50.

Gretzel, U., D. R. Fesenmaiers, and J. T. O'Leary. 2006. 'The Transformation of Consumer Behaviour.' In Tourism Business Frontiers, edited by D. Buhalis and C. Costa, 9-18. Oxford: Elsevier.

Holbrook, M. B., and E. C. Hirschman. 1981. 'The Experiential Aspects of Consumption: Consumer Fantasies, Feelings, and Fun.' Journal of Consumer Research 9 (September): 132-40.

Huerta-Alvarez, R., J. L. Cambra-Fierro, and M. Fuentes-Blasco. 2020. 'The Interplay between Social Media Communication, Brand Equity and Brand Engagement in Tourist Destinations: An Analysis in an Emerging Economy' Journal of Destination Marketing \& Management 16:100413. https://doi.org/10.1016/j.jdmm.2020.100413.

Hussain, T., B. Li, D. Wang. 2018. 'What Factors Influence the Sustainable Tour Process in Social Media Usage? Examining a Rural Mountain Region in Pakistan.' Sustainability 10 (7): 2220. https://doi.org/10.339o/ su10072220.

Jacobsen, J. K. S., and A. M. Munar. 2012. 'Tourist Information Search and Destination Choice in a Digital Age.' Tourism Management Perspectives 1:39-47.

Kašćelan, L., M. Pejić Bach, B. Rondović, and T. Đuričković. 2020. 'The Interaction between Social Media, Knowledge Management and Service Quality: A Decision Tree Analysis.' PLOS ONE 15 (8): e0236735.

Kim, J., and D. R. Fesenmaier. 2017. 'Sharing Tourism Experiences: The Posttrip Experience.' Journal of Travel Research 56 (1): 28-40.

Latif, K., M. Y. Malik, A. H. Pitafi, S. Kanwal, and Z. Latif. 2020. 'If You Travel, I Travel: Testing a Model of When and How Travel-Related Content Exposure on Facebook Triggers the Intention to Visit a Tourist Destination.' Sage Open 10 (2). https://doi.org/10.1177/ 2158244020925511.

Law, R., D. Buhalis, and C. Cobanoglu. 2014. 'Progress on Information and Communication Technologies in Hospitality and Tourism.' International Journal of Contemporary Hospitality Management 26 (5): 72550.

Leung, D., R. Law, H. van Hoof, and D. Buhalis. 2013. 'Social Media in Tourism and Hospitality.' Journal of Travel \& Tourism Marketing 30 (12): 3-22.

Li, F. 2020. 'Understanding Chinese Tourists' Motivations of Sharing Travel Photos in WeChat.' Tourism Management Perspectives 33:1-13. 
Li, C., S. Guo, C. L. Wang, and J. Zhang. 2020. 'Veni, Vidi, Vici: The Impact of Social Media on Virtual Acculturation in Tourism Context.' Technological Forecasting and Social Change 145:513-22.

Lin, S. Y., P. J. Juan, and S. W. Lin. 2020. 'A тА M Framework to Evaluate the Effect of Smartphone Application on Tourism Information Search Behavior of Foreign Independent Travelers.' Sustainability 12 (22): 9366. https://doi.org/10.339o/su12229366.

Mabić, M., D. Gašpar, and D. Lucović. 2017. 'Presence of Banks on Social Networks in Bosnia and Herzegovina.' Business Systems Research: International journal of the Society for Advancing Innovation and Research in Economy 8 (2): 59-70.

Malhotra, N. K. 2002. Marketingkutatás. Budapest: Közgazdasági és Jogi Kiadványok.

Månsson, M. 2011. 'Mediatized Tourism.' Annals of Tourism Research 38 (4): 1634-52.

Markus, Z., D. Perovic, S. Pekovic, and S. Popovic. 2019. 'Assessing Tourist Revisit Intention through the Sports and Recreational Services Offered.' Business Systems Research: International journal of the Society for Advancing Innovation and Research in Economy 10 (2): 141-50.

Marušić, Z., A. Aleksić, M. Pejić Bach, M. A. Omazić, and J. Zoroja. 2019. 'Determinants of Innovation in Hotel and Travel Agency Service Industry: Impact of Information and Communication Technologies and Enterprise Readiness.' Interdisciplinary Description of Complex Systems 17 (1B): 209-25.

Miguéns, J., R. Baggio, and C. Costa. 2008. 'Social Media and Tourism Destinations: Tripadvisor Case Study'. Advances in Tourism Research 26 (28): 1-6.

Molina, A., M. Gomez, A. Lyon, E. Aranda, and W. Loibl. 2020. 'What Content to Post? Evaluating the Effectiveness of Facebook Communications in Destinations.' Journal of Destination Marketing \& Management 18:100498. https://doi.org/10.1016/j.jdmm.2020.100498.

Moorthy, K., N. M. Z. N. Salleh, A. X. Jie, C. S. Yi, L. S. Wei, L. Y. Bing, and Y. Z. Ying. 2020. 'Use of Social Media in Planning Domestic Holidays: A Study on Malaysian Millennials.' Millennial Asia. https://doi.org/10.1177 /0976399620938503.

Moric, I. 2013. 'Clusters As a Factor of Rural Tourism Competitiveness: Montenegro Experiences.' Business Systems Research 4(2): 94-107.

Moro, S., and P. Rita. 2018. 'Brand Strategies in Social Media in Hospitality and Tourism.' International Journal of Contemporary Hospitality Management 30:343-64.

Munar, A. M., and J. K. S. Jacobsen. 2014. 'Motivations for Sharing Tourism Experiences through Social Media.' Tourism Management 43:46-54. 
Nayak, B. C., G. K. Nayak, and D. Jena. 2020. 'Social Recognition and Employee Engagement: The Effect of Social Media in Organizations.' International Journal of Engineering Business Management 12:1-12.

Paliokas, I., A. Patenidis, E. Mitsopoulou, C. Tsita, G. Pehlivanides, E. Karyati, S. Tsafaras, E. Stathopoulos, A. Kokkalas, and S. Diplaris. 2020. 'A Gamified Augmented Reality Application for Digital Heritage and Tourism.' Applied Sciences 10 (21): 7868. https://doi.org/10.339o/ app10217868.

Pan, S., J. Lee, and H. Tsai. 2014. 'Travel Photos: Motivations, Image Dimensions, and Affective Qualities of Places.' Tourism Management 40:59-69.

Pavelka, J. P. 2016. 'Smartphone Use During Travel.' Paper presented at the T T R A Canada 2016 Conference, Vail, CO, 14-16 June.

Pawlowska-Legwand, A, and L. Matoga. 2020. 'Disconnect from the Digital World to Reconnect with the Real Life: An Analysis of the Potential for Development of Unplugged Tourism on the Example of Poland.' Tourism Planning \& Development. https://doi.org/10.1080/21568316 .2020 .1842487 .

Peco-Torres, F., A. I. Polo-Pena, and D. M. Frias-Jamilena. 2020. 'Brand Personality in Cultural Tourism through Social Media.' Tourism Review. https://doi.org/10.1108/TR-02-2019-0050.

Renjith, S., A. Sreekumar, and M. Jathavedan. 2020. 'An Extensive Study on the Evolution of Context-Aware Personalized Travel Recommender Systems.' Information Processing \& Management 57 (1). https://doi.org/ 10.1016/j.ipm.2019.102078.

Roblek, V., M. Pejić Bach, M. Meško, and A. Bertoncelj. 2013. 'The Impact of Social Media to Value Added in Knowledge-Based Industries.' Kybernetes 42 (4): 554-68.

Seo, E. J., J. W. Park, and Y. J. Choi. 2020. 'The Effect of Social Media Usage Characteristics on e-wo M, Trust, and Brand Equity: Focusing on Users of Airline Social Media.' Sustainability 12 (4). https://doi.org/10.339o/ su12041691.

Sotiriadis, M. D. 2017. 'Sharing Tourism Experiences in Social Media: A Literature Review and a Set of Suggested Business Strategies.' International Journal of Contemporary Hospitality Management 29 (1): 179-225.

Tan, G. W. H., V. H. Lee, B. Lin, and K. B. Ooi. 2017. 'Mobile Applications in Tourism: The Future of the Tourism Industry?' Industrial Management \& Data Systems 117 (3): 560-81.

Tang, J., and H. Liu. 2015. 'Trust in Social Media.' In Synthesis Lectures on Information Security, Privacy, and Trust, edited by E. Bertino and R. Sandhu, 1-10. San Rafael, cA: Morgan \& Claypool.

Taylor, D. G. 2020. 'Putting the "Self" in Selfies: How Narcissism, Envy 
and Self-Promotion Motivate Sharing of Travel Photos through Social Media.' Journal of Travel \& Tourism Marketing 37 (1): 64-77.

Thinkwithgoogle. 2016. 'Travel Infographic: How Mobile Shapes the Customer Journey.' https://www.thinkwithgoogle.com/consumer-insights/ travel-infographic-mobile-shapes-customer-journey/.

Tomičić Furjan, M., K. Tomičić-Pupek, and I. Pihir. 2020. 'Understanding Digital Transformation Initiatives: Case Studies Analysis.' Business Systems Research: International Journal of the Society for Advancing Innovation and Research in Economy 11 (1): 125-41.

Tourwriter. 2020. 'The Future of Tourism: Travel Trends for 2021 and Beyond' https://www.tourwriter.com/travel-software-blog/future -tourism-2021/.

Travelers Today. 2019. 'Pros and Cons of Smartphones During Travel.' https://www.travelerstoday.com/articles/48598/20191014/pros-and -cons-of-smartphones-during-travel.html.

Usakli, A., B. Koc, and S. Sonmez. 2017. 'How "Social” Are Destinations? Examining European D мо Social Media Usage.' Journal of Destination Marketing \& Management 6 (2): 36-149.

Világgazdaság. (2020). 'A hároméves gyerekek fele már okoseszközöket használ.' https://www.vg.hu/kozelet/kozeleti-hirek/a-haromeves -gyerekek-fele-mar-okoseszkozoket-hasznal-2041725/.

Wang, D., S. Park, and D. R. Fesenmaier. 2012. 'The Role of Smartphones in Mediating the Touristic Experience.' Journal of Travel Research 51 (4): 371-87.

Wang, D., Z. Xiang, and D. R. Fesenmaier. 2016. 'Smartphone Use in Everyday Life and Travel.' Journal of Travel Research 55 (1): 52-63.

Wilcockson, T. D. W., A. M. Osborne, and D. A. Ellis. 2019. 'Digital Detox: The Effect of Smartphone Abstinence on Mood, Anxiety, and Craving.' Addictive Behaviors 99:1-4.

Wilkinson, L. 2013. 'Multidimensional Scaling.' http://cda.psych.uiuc.edu/ multivariate_fall_2013/systat_scaling_manual.pdf.

Woodside, A. G., and Lysonski, S. 1989. 'A General Model of Traveller Destination Choice.' Journal of Travel Research 27 (4): 8-14.

Yang, F. X., and I. A. Wong. 2020. 'The Social Crisis Aftermath: Tourist Well-Being During the CoviD-19 Outbreak.' Journal of Sustainable Tourism. https://doi.org/10.108o/o9669582.2020.1843047.

Yang, H. 2013. 'Bon Appétit for Apps: Young American Consumers Acceptance of Mobile Applications.' Journal of Computer Information Systems 53 (3): 85-96.

Yu, C. E., S. Y. Xie, and J. Wen. 2020. 'Coloring the Destination: The Role of Color Psychology on Instagram.' Tourism Management 80:104110. 